\title{
Inntak av marine fettsyrer hos nyretransplanterte
}

\begin{abstract}
Nyretransplanterte pasienter med høyt inntak av marine fettsyrer har bedre transplantatfunksjon, en mer gunstig kardiovaskulær risikoprofil, opplever færre avstøtningsreaksjoner og har høyere overlevelse.
\end{abstract}

Tidligere studier har vist varierende grad av forebyggende effekt mot hjerte- og karsykdom ved tilskudd av marine fettsyrer, også kalt omega-3-fettsyrer. Det har vært spekulert i om optimalisert blodfortynnende, antihypertensiv og kolesterolsenkende behandling har redusert betydningen av å spise fisk. Søkelyset er i de senere årene blitt rettet mot pasientgrupper som antas å ha spesielt stor nytte av å innta marine fettsyrer, herunder nyretransplanterte pasienter, som har en betydelig overdødelighet av kardiovaskulær sykdom. Man har ikke tidligere i store studier sett på betydningen av fiskeinntak hos organtransplanterte.

I denne studien av 1990 nyretransplanterte pasienter, med en median observasjonstid på syv år, viste vi at høye nivåer av marine fettsyrer i blod, som uttrykk for høyt inntak av fisk, var assosiert med lavere mortalitet og færre tapte transplantater. Gruppert etter nivå av marine fettsyrer hadde pasienter i øvre kvartil $56 \%$ lavere relativ risiko for død og $82 \%$ lavere relativ risiko for kardiovaskulær død. Høye nivåer av marine fettsyrer var assosiert med en gunstig kardiovaskulær risikoprofil, inklusive høyere HDLkolesterol og lavere triglyserider og fastende blodsukkernivåer og lavere hvilepuls.

Høye marine fettsyrenivåer var også assosiert med mindre fall i nyrefunksjon, færre avstøtningsreaksjoner etter den initielle fasen (første tre måneder) etter transplantasjon og bedre transplantatoverlevelse. Funnene gir grunnlag for hypoteser om nyrebeskyttende effekter av marine fettsyrer, som potensielt kan ha betydning for pasient- og transplantatoverlevelse.

\section{Ivar Anders Eide}

ivaeid@ous-hf.no

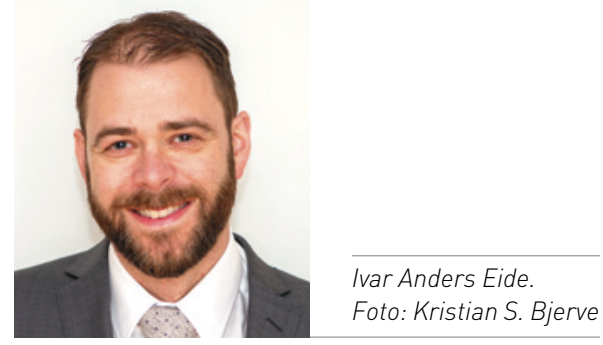

Disputas

Ivar Anders Eide disputerte for ph.d.-graden ved Universitetet i Oslo 22.4. 2016. Tittelen på avhandlingen er Marine $n-3$ polyunsaturated fatty acids in renal transplantation.

\section{Genetisk sårbarhet ved primær skleroserende kolangitt}

\section{Den genetiske sårbarheten for primær skleroserende kolangitt lokali- sert på kromosom 6 er kompleks.}

Primær skleroserende kolangitt har lenge vært den vanligste årsaken til levertransplantasjon i Norden. Progredierende og kronisk betennelse i gallegangene fører på sikt til leversvikt. Sykdommen rammer hyppigst unge menn og er forbundet med en rekke komorbiditeter, særlig inflammatorisk tarmsykdom og gallegangskreft. I de senere år er det i en rekke studier påpekt en genetisk sårbarhet for å utvikle primær skleroserende kolangitt.

I dette doktorarbeidet har vi arbeidet videre med genområdet som er forbundet med størst risiko for primær skleroserende kolangitt, nemlig «major histocompatibility complex» (MHC). Dette genområdet på kromosom 6 er det mest komplekse i det humane genom, med mer enn 250 tett koblede gener.

I vårt arbeid fant vi at risikoen i HLA-komplekset kan tilskrives flere gener og varianter av disse, men at især to klassiske HLA-gener (HLA-B og HLA-DRB1) ser ut til å ha stor betydning. Videre fant vi at ulik klinisk presentasjon av primær skleroserende kolangitt var forbundet med ulik genetisk risikoprofil for HLA-gener. Det ble også vist at de samme HLA-genene som er forbundet med risiko for primær skleroserende kolangitt også er forbundet med risiko for akutt avstøtning av transplantat etter levertransplantasjon, uavhengig av underliggende leversykdom.

Veien fra funn i genetiske studier til klinisk betydning er ofte lang. Dette doktorarbeidet er ett av mange steg på veien og vil danne grunnlag for videre forskning.

\section{Sigrid Næss}

nass.sigrid@gmail.com

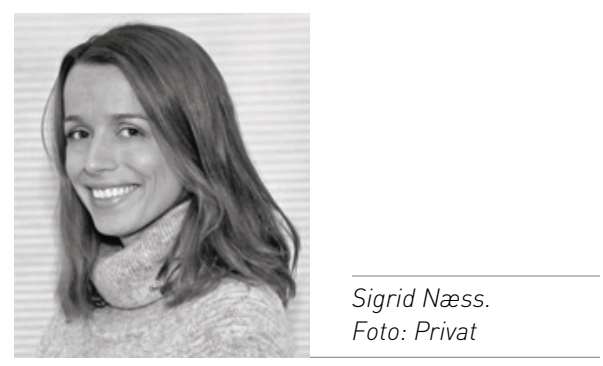

Disputas

Sigrid Næss disputerte for ph.d.-graden ved Universitetet i Oslo 15.12.2015. Tittelen på avhandlinger er The major histocompatibility complex association in primary sclerosing cholangitis. 